\title{
Genetic and dietary factors related to schizophrenia
}

\author{
Karl L. Reichelt ${ }^{1 *}$, Michael L. G. Gardner ${ }^{2}$ \\ ${ }^{1}$ Department of Pediatric Research, University of Oslo, Oslo University Hospitals, Oslo, Norway \\ ${ }^{2}$ School of Medical Sciences, University of Bradford, Bradford, UK \\ Email: "karl@ulrik.uio.no
}

Received 19 October 2011; revised 20 November 2011; accepted 30 November 2011

\begin{abstract}
Biochemical, immunological and epidemiological evidence increasingly support the suggestion that there is a causal relationship between gluten/gliadin and schizophrenia as originally proposed by F. C. Dohan. Furthermore the necessary physiological mechanisms exist to explain a mechanism involving bioactive peptides from these proteins, and these show that this mechanism is possible and probable in at least in a substantial subgroup of schizophrenic patients. Evidence shows a fairly strong genetic disposition, and it must be recognised that any genetic mechanism must implicate altered chemistry and function of proteins. Evidence supports the likelihood that dietary intervention is beneficial for some, and this demands further investigation. A similar conclusion may apply to autism spectrum conditions.
\end{abstract}

Keywords: Schizophrenia; Peptides; Antibodies; Food Proteins

\section{INTRODUCTION}

Many studies have shown a genetic disposition for schizophrenia [1-3] as have studies on children of schizophrenic mothers who have been adopted into other families. [4]. Genetic conditions must of necessity involve chemical changes in proteins which, in turn, cause changes in protein function. Changes in the genome that do not cause changes of protein function are false leads and will not explain the pathogenesis of schizophrenia. Defects of enzyme activity are obvious candidates for dysfunction; but receptors, transport proteins and channel forming proteins should also be regarded as specialized enzymes susceptible to defects. Decreased function in any metabolic pathway will usually cause an increase in the level of prelesion metabolites (Figure 1). A typical example is phenylketonuria where phenylalanine hydroxylase in the liver has insufficient activity. Phenylalanine levels in blood and cells increase as does the flux along secondary pathways utilising phenylalanine. Reducing the input of

\footnotetext{
*Corresponding author.
}

phenylalanine prevents the cogntive impairment known as Föllings disorder.

It should also be noted that any restriction in a metabolic pathway may cause changes in flux through apparently unrelated pathways, and hence abnormal levels of metabolites in these pathways. This will be the case in a pathway, altered by genetic and functional abnormality, where coenzymes are involved which also function in other paths, e.g. biopterins which have major roles in several neurotransmitter pathways. Hence, measurement of metabolites in a pathway may give a misleading impression that that pathway is the site of a lesion. It is also important to recognise that regulation of most pathways is implemented at rate-controlling steps: hence, any alteration at other steps in the pathway that interferes with activity, and may make that step a non-physiological rate-limiting step, involves a potentially serious disruption of the normal physiological regulation of that pathway.

Hence, identification of affected pathways and the enzymes (or related proteins) is crucial for explanation of mechanisms, including the genetic basis, of schizophrenia. Further, identification of environmental factors that interact with a genetic predisposition to cause schizophrenia is vital, especially as this potentially can lead to "cure" or, at least, better management of schizophrenia

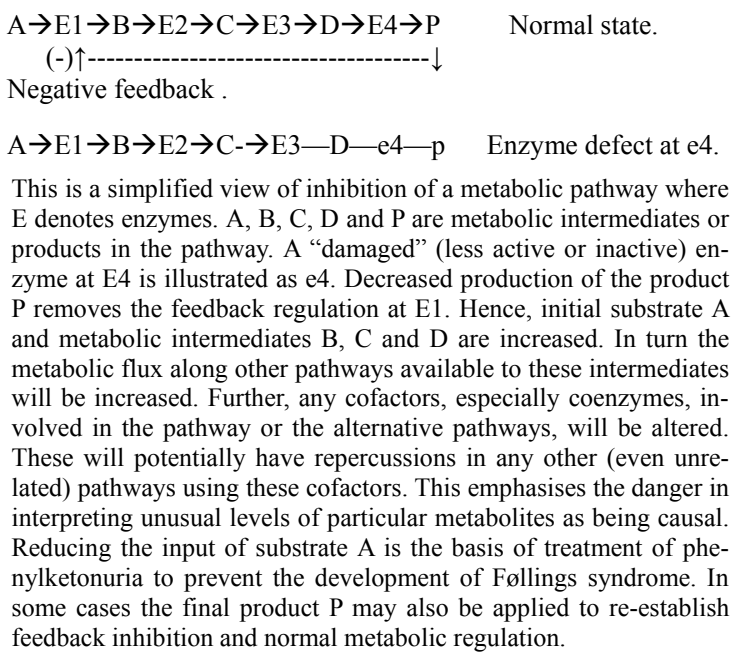
products in the pathway. A "damaged" (less active or inactive) enzyme at E4 is illustrated as e4. Decreased production of the product $P$ removes the feedback regulation at $E 1$. Hence, initial substrate $A$ and metabolic intermediates B, C and D are increased. In turn the metabolic flux along other pathways available to these intermediates will be increased. Further, any cofactors, especially coenzymes, involved in the pathway or the alternative pathways, will be altered. These will potentially have repercussions in any other (even unrelated) pathways using these cofactors. This emphasises the danger in interpreting unusual levels of particular metabolites as being causal. Reducing the input of substrate $\mathrm{A}$ is the basis of treatment of phenylketonuria to prevent the development of Føllings syndrome. In some cases the final product $\mathrm{P}$ may also be applied to re-establish feedback inhibition and normal metabolic regulation.

Figure 1. Consequences of enzyme defect. 
even in genetically predisposed people.

Previous evidence, outlined subsequently, makes us focus on diet as a relevant factor in the aetiology of schizophrenia and, hence, in its clinical management. Specifically, evidence points to gluten, the major protein in wheat, and its gliadin peptides, as being relevant in, at least, a sub-set of schizophrenics. While we discuss schizophrenia here, it should be noted that similar preliminary evidence exists for similar mechanisms in the aetiology of autism. It must be stressed that both schizophrenia and autism almost certainly involve multiple aetiologies, and no patient group should be regarded as homogeneous. Studies must look for sub-sets (endophenotypes) among patients which will relate to differing biochemical aetiologies and differing management plans.

To relate to schizophrenia the following conditions must be satisfied:

A: There must be chemical changes that can be measured and defined;

B: It must be shown with reasonable probability that removal of the offending source of the accumulated compounds is effective; and

C: The patho-physiology of the disease ought to be plausibly explained in terms of known physiological mechanisms.

A. Increase in various compounds found.

Various fractions of serum from schizophrenic patients have long been known to induce behavioural changes in animals [5,6] and also in man [7]. However attempts to characterise the chemical nature of the factor(s) responsible have always failed as these activities were invariably lost during purification. This process mirrors what happens to low molecular weight peptides which bind to proteins and other macromolecules.

We believe that the strong affinity of peptides for each other and other macromolecules especially proteins $[8,9]$ has been responsible for many relevant peptides being lost during purification protocols. Conditions of $\mathrm{pH}$ and ionic strength during pre-analysis preparation markedly affect the attachment of peptides [9] although this does not appear to have been investigated systematically.

It was also found that urine fractions from schizophrenic people could alter behaviour in rats [10].

These fractions showed increased levels of bioactive peptides [11,12] and this finding was promptly confirmed by other authors[13-16]. In particular, opioid activity studied by the tail flick bioassay [11] was found. The fractions also inhibited dopamine uptake in synaptosomes from the striatum, and caused hyperactivity of the dopamine system demonstrated by the Ungerstedt model in vivo [11].The hyperactivity initially induced in the rats later turned into a catatonic state [11]. Injecting intracranially gliadin derived peptides caused similar behavioural changes to be observed [17].
Chemical analysis of urinary peptides presents numerous difficulties. However, a reverse-phase (HighPerformance Liquid Chromatography) HPLC method based on that detailed by ourselves [18] proves to be satisfactory, separating hydrophilic molecules from the hydrophobic, (which include short chain peptides): the latter elute in the 2nd half of the chromatographic run [18] Further characterization of the eluted molecules can be provided by on-line mass spectrometry [19]. This has enabled the identification of several exorphin peptides, including casomorphins. Figure 2 shows the HPLC of a control subject and 2B a paranoid schizophrenic (F 20.0).

The presence of pharmacologically active peptides arising in humans during digestion of dietary proteins has attracted remarkably little attention. However Zioudrou et al. [20] produced important data indicating that peptic digestion of gluten could produce small peptides with opioid activity; and they named these "exorphins" because of their similar activity to the endogenous family of endorphins. These peptides have been sequenced, and it is noteworthy that gluten, the major protein in wheat, contains many sequences in its primary structure [21]. Gardner summarised the evidence of Fukudome and Yoshikawa $[22,23]$ thus: The gluten exorphins have also been sequenced, and it is most striking that one of these sequences A5 (Gly-Tyr-Tyr-Pro-Thr) occurs 15 times in the primary structure of glutenin, a component of gluten. This peptide was reported to be highly specific for for $\delta$ opiate receptors. The most potent gluten exorphin, named B5 by Fukudome and Yoshikawa, was Tyr-GlyGly-Trp-Leu, which has the same 3 N-terminal amino acids as enkephalin, and their potencies against guinea pig ileum are closely similar. A further sequence, TyrPro-Ile-Ser-Leu, named exorphin $\mathrm{C}$, was also active in the classical guinea pig ileum and mouse vas deferens bioassays. It is thus clear that gluten is potentially a very rich source of opioid peptides.

Gardner [24] after searching early protein sequence databases, reported that many proteins contain amino acid sequences corresponding to bioactive peptides. These observations indicate that dietary proteins can yield peptides during digestion which, if not digested further, have the potential to interfere with neural regulation. Because opioid peptides can interfere also with immune processes, the possibility for serious physiological disruption is obvious.

Other authors, notably Brantl et al. [25], reported that enzymic digestion of casein, the major protein in milk, also could yield a series of opioid peptides which they named "casomorphins" These exorphins could potentially explain the epidemiology of schizophrenia in relation to diet and also many of the symptoms of the disorder [15]. Intravenous injection of $\beta$-casomorphin 1-7 in rats induced the same behavioural changes as seen after intra-cranioventricular injection [26], indicating passage 

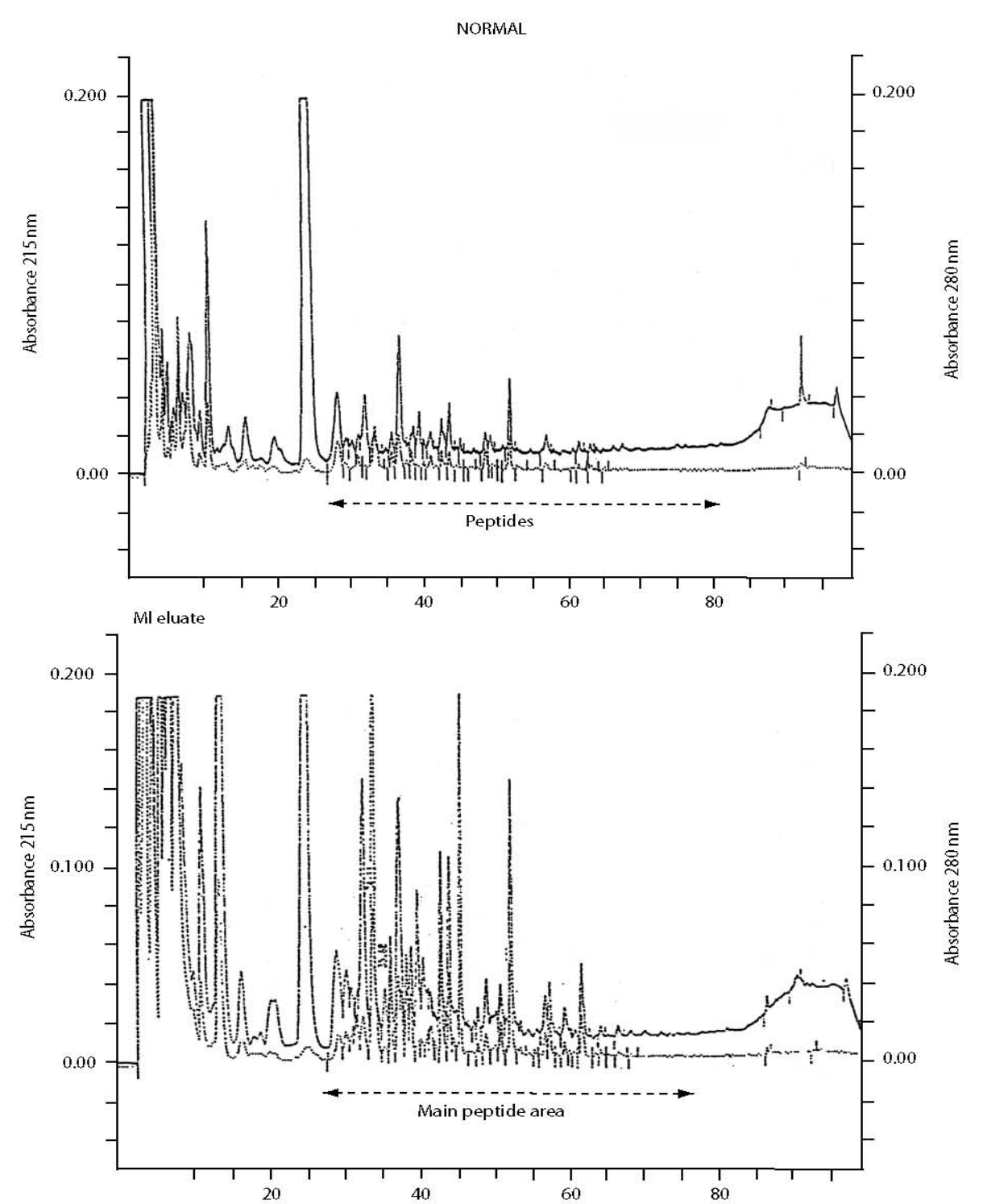

The peptides have been separated by HPLC on a C18 reverse phase column using (TFA) Trifluoroacetic acid $(10 \mathrm{mM})$ and acetonitril gradient as described. [18].

Figure 2. Normal and paranoid schizophrenic urine patterns.

across the blood-brain barrier. Beta-casomorphin 1-7 also caused FOS antigen increase (immediate early gene) in many of the key nuclei involved in schizophrenia [27], blocked by the opiate antagonist naloxone. Interestingly Lindström et al. [28] had proposed that the symptom-rich diagnosis of post-partum psychosis may be due to casomorphin increase in CSF.

Elevated levels of IgA antibodies to gluten, gliadin, casein and in a few cases lactoglobulin, was found in serum of schizophrenics [29] and points to a potential gutbrain link. Antibodies that may implicate gliadin in schizophrenia have also been reported [30-34] and also antibodies to casein [35]. Although most cases are not celiac disease [31], there is a higher than expected frequency of schizophrenia in celiac disorders [36-38] and schizoph- renic patients may share some antibodies but without presenting with celiac disease.

Whether these antibodies are caused by peptides attaching to proteins and acting as epitopes or as conformation-changing factors as found in autism [8,39], or if it is the increased uptake of macromolecules directly, remain unanswered. The combined data point to these food proteins being key factors, as suggested by Dohan [40], who also found antibody increases [41], and is discussed more extensively elsewhere [42].

\section{EFFECT OF REMOVING PROBABLE CAUSATIVE FOODS FROM THE DIET}

In a series of classic studies on schizophrenia in various 
populations Dohan reported on a relationship between wheat consumption and the incidence of schizophrenia [40], and that where schizophrenia was rare, the intake of grains containing gluten and gliadin was rare [43]. Removal of gluten from the diet was found to shorten hospital stay in relapsed cases [44] and showed a beneficial effect as demonstrated by Singh and Kay [45]. A completely blind study of the chemistry in ten semi-chronic patients on and off diet for 16 weeks gave statistically significant improvements [46] and was confirmed [16]. However, as the measurable anatomical changes in the brain are fastest in the first few years after diagnosis [47], this was not an ideal group for such a test. Semi-chronic and chronic cases of schizophrenia have evidence of clear decreased volume of several brain areas. Furthermore, it took 28 weeks of gluten-free diet for the urinary peptide pattern to revert to normal [46].

Several negative series of chronic patients over very short times have been reported [48-51], but, even so, some individuals in the groups seemed to respond dramatically to dietary change [51]. There are several case reports that show effect of diet [52-54]; it is likely that a subgroup of unknown magnitude may belong to a gluten-sensitive subgroup.

While the demonstration by Vlissides, et al. [51] of dramatic improvement in 2 paranoid schizophrenic patients, who had histories of illness of over 18 years and had been hospitalised in a secure institution after multiple criminal acts, lacks statistical power due to the number of subjects and the short duration of the trial of the gluten-free diet, the effects were so dramatic that results should not be discarded. The 2 patients who had initially benefited from dietary intervention regressed badly on reintroduction of gluten-containing foods. However the practical difficulties in conducting such studies are formidable.

Unfortunately our methods for urinary peptide analysis (see below) at the time of that study were not well enough developed to investigate any biochemical features in the responsive patient group. Nor were we able to measure intestinal permeability ("leakiness") in these patients and the suggestion of some effect.

Cade et al. [16] studied a group of 120 schizophrenics, some over many years. Eighty-six per cent of them had high levels of $\operatorname{IgA}$ antibodies to gluten. They reported significant improvements in objective psychiatric assessments and major reductions in the peaks in the "peptide and peptide-like" hydrophobic region of urine chromatograms after imposition of a gluten- and casein-free diet. In the same report, they provided evidence of similar benefits of this diet in a group of 70 autistic children, some of whom had been monitored for up to 8 years on the diet. It seems likely that some sub-sets of schizophrenics and some sub-sets on the autistic spectrum share similar metabolic defects. The changes in the chromatographic profiles associated with the diet were dramatic and clearly represent a reduction in more than one or two peptides such as the known exorphins; these findings provide independent corroboration of those reported by Reichelt and colleagues [11].

\section{WOULD THIS EXPLAIN THE PATHOPHYSIOLOGY OF THE DISEASE?}

A promising explanation of the symptoms in autism related to an opioid effect has been published [15] and it was interesting that opioid peptide from schizophrenics were linked to hyperactivity, analgesia and after a time, catatonia-like states in rats [11]. Opioids also inhibited the uptake of dopamine into striatal synaptosomes and caused in-vivo hyper-dopaminergic activity using the Ungerstedt model [11] Excess of dopaminergic activity is somehow related to psychoses. Peptides that dissociate from non-covalently bound proteins could easily explain the many serum factors found [42]. Peptide increase in urine is usually due to breakdown defects $[55,56]$ but reabsorption in kidney tubuli defects may also cause peptiduria.

The reported increased incidence of schizophrenia in immigrants from low gluten consumption countries to Europe [57] could be also explained by the increased intake of these food. Earlier manifestation of schizophrenia in boys than in girls may be linked to the greater intake of bread and milk by boys as teenagers [42]. Given that peptides and proteins like antibodies to gliadin apparently are damaging to brains [58], and opioids have morphological effects on nerve tissue and development $[59,60]$ this makes sense. Antibodies to gliadin are reported to induce apoptosis in cerebellar Purkinje cells [58].

\section{IS THIS POSSIBLE OR PROBABLE}

To be possible there must be physiological mechanisms that can explain how a gut to brain relationship may be possible and probable. Peptides with affinity to opioid receptors arise in the small intestine of man during protein digestion [61,62]. Initially, Dohan, Reichelt and others could not see how peptides of dietary origin could enter the circulation in an intact bioactive form to support their hypothesis of dietary involvement, since the accepted dogma of protein digestion and absorption at that time was that free amino acids were the only product of protein digestion that could enter the circulation [63]. However it soon became recognised that this view was incorrect, and a strong body of evidence for intestinal absorption of peptides, and even of small amounts of intact proteins, was collected [64] and is now irrefutable.

Further, increased peptide absorption would be ex- 
pected if intestinal peptide digestion was impaired or if there was increased intestinal permeability, e.g. especially if the mucosa was inflamed. Increased intestinal permeability, now readily measurable by oral administration of "non-absorbable" test molecules which are recovered in urine, has been reported in sub-sets of schizophrenic and autistic patients [65-67], though no studies yet have investigated any potential correlation with urinary peptide output. Some authors claiming that this increase is not statistically significant have neglected the fact that the patient results show a skewed distribution: inspection of scatter diagrams of the data clearly reveal outliers, a subset, with unusually high permeability. In autism increasing data show increased gut permeability [68] Release of inflammatory cytokines by milk and grains have been reported in autism [69]. Peptidase inhibition can cause increased peptide uptake [70,71], and peptidase inhibitors from food demonstrate this phenomenon [71]. The body is also able to take up intact proteins $[64,72]$ and if these are not broken down completely, peptides can accumulate. Furthermore proteins ingested by mothers can be recovered from their milk [73]; more so if autoantibodies to the key peptidase di-peptidylpeptidase IV (DPP-IV) (CD26) [8] are formed. Botulinum toxin is a protease and biologically significant quantities are taken up and pass the blood brain barrier and further split SNAP-25 in the synaptosomes with a potentially fatal outcome [74]. Other enzymes have been demonstrated to be absorbed across the gut with retained activity [75]. Furthermore peptides (and possibly some proteins) can cross the blood brain barrier [76,77]. An increase in the blood - brain barrier permeability has also been found in schizophrenia [78,79]. Therefore the mechanisms to explain a diet-gut-to-brain relationship can be established.

\section{PHYSIOLOGICAL EVIDENCE OF A GUT TO BRAIN RELATIONSHIP}

Evidence for the plausibility of a gut-brain relationship is demonstrated by coeliac children, who show long lasting EEG changes on provocation with gliadin after having been on a gluten-free diet [80]. Also children with Attention Deficit (Hyperactivity) Disorder (ADHD) show magnetic EEG changes after exposing children to food to which they are "intolerant", although the mediators are unknown[81] In cases of inflammatory bowel disease exposure to foods cause widespread perivascular oedema mediated by unknown factors, in the white substance of the brain [82,83] Results for autistic children are very similar in peptide pattern and also show 1-2 $\mathrm{pH}$ units higher level than controls as do schizophrenics. In autism gliadin and casein releases inflammatory cytokines in the stomach [68] and such cytokines increase transepithelial barrier transport [84] thus potentially reinforcing this view. It has also been established that persons with gastrointestinal disorders such as inflammatory bowel disease have an increased incidence of psychiatric disorders including depression [85-87]. Autopsy found signs of chronic inflammation [88] and a summary [89] of Buscaino's data from 82 autopsies on schizophrenics found enteritis in $88 \%$, colitis in $92 \%$ and gastritis in $50 \%$. Clinical data [36] found a highly significant increase in schizophrenia in cases with Irritable Bowel Syndrome (IBS) reinforcing a gut to brain connection in schizophrenia.

\section{CONCLUSION}

There is now considerable evidence that schizophrenia, at least in some patients, may be a combined genetic and dietary disorder. Further studies are urgently needed to extend the available data. Attention to this should provide a scientific basis for more aetiologically based treatment. Similar conclusions are likely to apply to somegroups diagnosed with an autism spectrum condition. It is essential to recognise that both these conditions almost certainly have multiple aetiologies so that patients fall into distinct sub-sets rather than a homogeneous population.

\section{REFERENCES}

[1] Kendler, K.S. and Diehl, S.R. (1993) The genetics of schizophrenia: A current genetic-epidemiologic perspective. Schizophrenia Bulletin, 19, 261-286.

[2] Gottesman, I.I. and Betelsen, A. (1989) Confusing unexpected phenotypes for schizophrenia. Risks in the offspring of Fischer's Danish identical and fraternal twins. Archives of General Psychiatry, 46, 867-872. doi:10.1001/archpsyc.1989.01810100009002

[3] Onstad, B., Skre, I., Torgersen, S. and Kringlen, E. (1991) Twin concordance for DSM-III-R Schizophrenia. Acta Psychiatrica Scandinavica, 83, 396-401. doi:10.1111/j.1600-0447.1991.tb05563.x

[4] Mednick, S.A., Schuolsinger, F., Higgins, J., Bell, B., Venables, P.H. and Christiansen, K.O. (1974) Genetics, environment and psychpathology. Elsevier, North Holland Press, New York.

[5] Frohman C.E., Czaijkowski, N., Luby, E.D., Gottlieb, J.B. and Senf, R. (1960) Further evidence of a plasma factor in schizophrenia. Archives of General Psychiatry, 2, 263267. doi:10.1001/archpsyc. 1960.03590090011003

[6] Berger, J.R., Gray, F.W. and Punnell, R.B. (1965) Tarexein-like extracts: Effects on rat behavior. Archives of General Psychiatry, 22, 80-82. doi:10.1001/archpsyc.1965.01720310082011

[7] Heath, R.G., Martens, S., Leacvh, B.E., Cohen, M. and Angel, C. (1957) Effect on behaviour in humans with the administration of tarexein. American Journal of Psychiatry, 114, 14-24. 
[8] Vojdani, A., Pangborn, J.B., Vojdani, E. and Cooper, E.L. (2003) Infections, toxic chemicals and dietary peptides binding to lymphocytes receptors and tissue enzymes are major instigators of autoimmunity in autism. International Journal of Immunopathology and Pharmacology, 16, 189-199.

[9] Reichelt K.L. (2007) Low molecular weight peptides. In: Lajhta, A., Oja, S.S., Schousboe, A and Saransaari, P. Eds., Handbook of Neurochemistry and Molecular Neurobiology. (Amino acids and peptides in the nervous system), Springer, New York, 402-411. doi:10.1007/978-0-387-30373-4 16

[10] Wada, J. and Gibson, W.C. (1959) Behavioral and EEG changes induced by injection of schizophrenic urine extracts. Archives of Neurology and Psychiatry, 81, 747-764.

[11] Hole, K., Bergslien, A.A., Jørgensen, H., Berge, O.-G., Reichelt, K.L. and Trygstad, O.E. (1979) A peptide-containing fraction from schizophrenia which stimulates opiate receptors and inhibits dopamine uptake. Neuroscience, 4, 1139-1147. doi:10.1016/0306-4522(79)90062-9

[12] Reichelt, K., L1 Hole, K., Hamberger, A., Sælid, G., Edminson, P.D., Braestsrup, C.I., et al. (1981) Biologically active peptide-containing fractions in schizophrenia and childhood autism. Advances in Biochemical Psychopharmacology, 28, 627-649.

[13] Drysdale, A., Deacon, R., Lewis, P., Olly, J., Electricwala, A. and Sherwood, R. (1982) A peptide containing fraction of plasma of schizophrenic patients which binds to opiate receptors and induces hyperactivity in rats. Neuroscience, 7, 1567-1574. doi:10.1016/0306-4522(82)90265-2

[14] Idet, M., Grof, J., Menyhart,J. and Pajor, A. (1982) Elevated opioid activity in sera of chronic schizophrenia. Acta Physiologica Hungarica, 60, 121-127.

[15] Lindström, L.H., Besev, G., Gunne, L.M. and Terenius, L. (1986) CSF levels of receptor-active endorphins in schizophrenic patients: Correlation with symptomatology and monoamine metabolites. Psychiatry Research, 19, 93-100. doi:10.1016/0165-1781(86)90001-6

[16] Cade, R., Privette, M., Fregly, M., Rowland, N., Sun, Z., Zele,V., et al. (2000) Autism and schizophrenia: Intestinal disorders. Nutritional Neuroscience, 3, 57-72.

[17] Dohan, F.C., Levitt, D.R. and Hushnir, L.D. (1978) Abnormal behaviour after intracerebral injection of polypeptides from wheat gliadin. Pakistan Journal of Biological Sciences, 13, 73-82.

[18] Reichelt, W.H., Stensrud, M.B. and Reichelt, K.L. (1998) Peptide excretion in celiac disease. Journal of Pediatric Gastroenterology and Nutrition, 26, 305-309. doi:10.1097/00005176-199803000-00012

[19] Liu, Y., Heiberg, T. and Reichelt, K.L. (2007) Towards a possible aetiology for depressions? Behavioral and Brain Functions, 3, 47-53. doi:10.1186/1744-9081-3-47

[20] Zioudrou, C., Streaty, R.A. and Klee, W.A. (1979) Opioid peptides derived from food proteins. The exorphins. The Journal of Biological Chemistry, 254, 2446-2449.

[21] Gardner, M.L.G. (1994) Absorption of intact proteins and peptides. In: Johnson, L.R., Ed., Physiology of the Gas- trointestinal Tract, 3rd Edition, Raven Press, New York, pp. 1791-1820.

[22] Fukudome, S. and Yoshikawa, M. (1992) Opioid peptides derived from what gluten: Their isolation and characterisation. FEBS Letters, 296, 107-111. doi:10.1016/0014-5793(92)80414-C

[23] Fukudome, S. and Yoshikawa, M. (1993) A novel opioid peptides derived from what gluten. FEBS Letters, 316, 17-19. doi:10.1016/0014-5793(93)81727-H

[24] Gardner, M.L.G. (1985) Production of pharmacologically active peptides from foods and the gut. In: Hunter, J.O. and Jones, V.A., Eds., Food and the Gut. Bailliere Tindall, London, 121-134.

[25] Brantl, V., Teschemacher, H., Henschen, A. and Lottspeich, F. (1979) Novel opioid peptides derived from casein ( $\beta$-casomorphins). Isolation from bovine casein peptone. Hoppe-Seyler's Zeitschrift für physiologische Chemie, 360, 1211-1216. doi:10.1515/bchm2.1979.360.2.1211

[26] Sun, Z. and Cade, J.R. (1999) A peptide found in schizophrenia and autism causes behavioural changes in rats. Autism, 3, 85-95. doi:10.1177/1362361399003001007

[27] Sun, Z., Cade, R.J., Fregly, M.J. and Privette, R.M. (1999) Beta-casomorphine induces Fos-like immunoreactivity in discrete brain regions relevant to schizophrenia and autism. Autism, 3, 67-83. doi:10.1177/1362361399003001006

[28] Lindström, L.H., Nyberg, F., Terenius, L., Bauer, K., Besev, G., Lyrenäs, L.M., et al. (1984). CSF and Plasma beta-casomorphin-like opioid peptides in postpartum psychosis. The American Journal of Psychiatry, 141, 10501066.

[29] Reichelt, K.L. and Landmark, J. (1995) Specific IgA antibody increases in schizophrenia. Biological Psychiatry, 37, 410-413. doi:10.1016/0006-3223(94)00176-4

[30] Samaroo, D., Dickerson, F., Kasarda, D.D., Green, P.H.R., Briani, C., Yolken, R.H., et al. (2010). Novel immune response to gluten in individuals with schizophrenia. Schizophrenia Research, 118, 248-255. doi:10.1016/j.schres.2009.08.009

[31] Dickerson, F., Stallings, C., Origoni, A., Vaughan, C., Khushalani, S., Leister, F., et al. (2010) Markers of gluten sensitivity and celiac disease in recent-onset psychosis and multi-episode schizophrenia. Biological Psychiatry, 58, 100-104. doi:10.1016/j.biopsych.2010.03.021

[32] Cascella, N.G., Kryszak, D., Bhatti, B., Gregory, P., Kelly, D.L., McEvoy, J.P., et al. (2011) Prevalence of celiac disease and gluten sensitivity in the United States. Clinical Antipsychotic trials of intervention, Effectiveness study Population. Schizophrenia Bulletin, 37, 94-100. doi:10.1093/schbul/sbp055

[33] Jin, S., Wu, N., Xu, Q., Zhang, X., Ju, G.-Z., Law, M.H. and Wei, J. (2011) A study of cocirculating gliadin antibodies in schizophrenia among Chinese population. Schizophrenia Bulletin, 37, 748-752.

[34] Niebuhr, D.W., Li, Y., Cowan, D.N., Weber, N.S., Fisher, J.A., Ford, G.M. and Yolken, R. (2011) Association of bovine casein antibody and new onset schizophrenia 
among US military personnel. Schizophrenia Research, 128, 51-55. doi:10.1016/j.schres.2011.02.005

[35] Severance, E.G., Dickerson, F.B., Halling, M., Krivogorsky, B., Haile, L., Yang, S., et al. (2010) Subunit and whole molecule specificity of anti-bovine casein immune response in recent onset psychosis and schizophrenia. Schizophrenia Research, 118, 240-247.

[36] Gupta, S., Masand, P.S., Kaplan, D., Dhandadary, A. and Hendricks, S. (1997) The relationship between schizophrenia and irritable bowel syndrome (IBS). Schizophrenia Research, 23, 265-268. doi:10.1016/S0920-9964(96)00099-0

[37] Eaton, W.W., Mortensen, P.B., Agerbo, E., Byrne, M., Mors, O. and Ewald, H. (2004). Coeliac disease and schizophrenia: Population based case control study with linkage of Danish national registers. British Medical Journal, 328, 438-439. doi:10.1136/bmj.328.7437.438

[38] Kalaydjian, A.E., Eaton, W., Cascella, N. and Fasano, A. (2005). The gluten connection: The association between schizophrenia and celiac disease. Acta Psychiatrica Scandinavica, 113, 82-89. doi:10.1111/j.1600-0447.2005.00687.x

[39] Vojdani, A., O’Brian, T., Green, J.A., McCandless, J., Woeller, K.N., Vojdani, E., et al. (2004) Immune response to dietary protein gliadin and cerebellar peptides in children with autism. Nature Neuroscience, 7, 151-161. doi: $10.1080 / 10284150400004155$

[40] Dohan, F.C. (1966) Cereals and schizophrenia. Data and hypothesis. Acta Psychiatrica Scandinavica, 42, 125-152. doi:10.1111/j.1600-0447.1966.tb01920.x

[41] Dohan, F.C., Martin, L., Grasberger, J.C., Boehme, D. and Cotrell, J.C. (1972) Antibodies to wheat gliadin in blood of psychiatric patients. Possible role of emotional factors. Biological Psychiatry, 5, 127-131.

[42] Reichelt, K.L., Seim, A.R. and Reichelt, W.H. (1996) Could schizophrenia be reasonably explained by Dohan's hypothesis on genetic interaction with a dietary peptide overload? Progress in Neuro-Psychopharmacology and Biological Psychiatry, 20, 1083-1114. doi:10.1016/S0278-5846(96)00099-1

[43] Dohan, F.C., Harper, E.M., Clark, M.H., Rodrigue, R.B. and Zigas, V. (1984) Is schizophrenia rare if grain is rare? Biological Psychiatry, 19, 385-399.

[44] Dohan, F.C. and Graasberger, J.C. (1973) Relapsed schizophrenics: Earlier discharge from the hospital after cereal-free, milk-free diet. American Journal of Psychiatry, 30, 685-686.

[45] Singh, M.M. and Kay, S.R. (1976) Wheat gluten as a pathogenic factor in schizophrenia. Science, 181, 401-402. doi:10.1126/science. 1246624

[46] Reichelt, K.L., Sagedal, E., Landmark, J., Sangvik, B.T., Eggen, O. and Scott, H. (1990) The effect of gluten-free diet on urinary peptide excretion and clinical state in schizophrenia. The Journal of Orthomolecular Medicine, 5, 223-239.

[47] Madsen, A.L., Karle, A., Rubin, P., Cortsen, M., Andersen H.S., and Hemmingsen, R. (1991) Progressive atrophy of the frontal lobes in first episode schizophrenia: In- teraction with clinical curse and neuroleptic treatment. Acta Psychiatrica Scandinavica, 100, 367-374. doi:10.1111/j.1600-0447.1999.tb10880.x

[48] Rice, J.R., Ham, C.M. and Gore, W.E. (1978) Another look at gluten in schizophrenia. American Journal of Psychiatry, 135, 1147-1148.

[49] Potkin, S.G., Weinberger, D., Kleiman, J., Nasrallah, H., Luchins, D. and Bigelow, I. (1981) Wheat gluten challange in schizophrenic patients. American Journal of Psychiatry, 138, 1208-1211.

[50] Storms, L.H., Clopton, J.M. and Wright, C. (1982) Effects of gluten in schizophrenics. Archives of General Psychiatry, 39, 323-327. doi:10.1001/archpsyc. 1982.04290030055010

[51] Vlissides, D.N., Venulet, A. and Jenner, F.A. (1986) A double blind gluten-free gluten load controlled trial in a secure ward population. The British Journal of Psychiatry, 148, 447-452. doi:10.1192/bjp.148.4.447

[52] Jansson, N., Kristjansson, E., Nilsson, L., et al. (1984) Schizophren psykosbild avklingade när pasientengavs gluen fri kost. Läkartidningen, 81, 148-149.

[53] Graff, K. and Handford, A. (1961) Celiac syndrome in the case histories of five schizophrenics. Psychology Quarter, 35, 306-313. doi:10.1007/BF01566581

[54] De Santis, A., Addolorato, A., Romito, S., Caputo, A., Giordano, G., Gambassi, C., et al. (1997) Schizophrenia symptoms and spectrum abnormalities in a coeliac patient: Regression after a gluten-free diet. Journal of Internal Medicine, 242, 421-423. doi:10.1046/j.1365-2796.1997.00200.x

[55] Abassi, Z., Golomb, E. and Keiser, H.R. (1992) Neutral endopeptidase inhibition increases urinary excretion and plasma level of endothelin. Metabolism, 41, 683-685. doi:10.1016/0026-0495(92)90303-R

[56] Watanabe,Y., Kojima-Kumatsu, T., Iwaki-Egewa, S. and Fujimoto, Y. (1993) Increased excretion of proline-containing peptides in dipeptidyl peptidase IV deficient rats. Research Communications in Chemical Pathology \& Pharmacology, 81, 323-350.

[57] Cantor-Graae, E. and Selten, P (2005) Schizophrenia and migration: A meta-analysis and review. American Journal of Psychiatry, 16, 12-24.

doi:10.1176/appi.ajp.162.1.12

[58] Hadjivassiliou, M., Boscolo, S., Davies-Jones, G.A.B., Grünewald, R.A., Not, T., Sanders, D.S., et al. (2002) The humoral response in the pathogenesis of gluten ataxia. Neurology, 58, 1221-1226.

[59] Zagon, I.S. and McLaughlin, P.J. (1987) Endogenous opioid systems regulate cell proliferation in the developing rat brain. Brain Research, 412, 68-72. doi:10.1016/0006-8993(87)91440-5

[60] Hauser, K.F., McLaughlin, P.I. and Zagon, I.S. (1989) Endogenous opioid systems and the regulation of dendritic growth and spine formation. The Journal of Comparative Neurology, 281, 13-22. doi:10.1002/cne.902810103

[61] Svedberg, J., De Haas, J., Leimanstoll, G., Paul, F., Teschemacher, H. (1985) Demonstration of beta-casomo- 
rphin immunoreactive materials in in vitro digests of bovine milk and in small intestinal contents after bovine milk ingestion in adult humans. Peptides, 6, 825-831. doi:10.1016/0196-9781(85)90308-0

[62] Chabance, B., Marteau, P., Rambaud, J.C., MiglioreSamour, D., Boynard, M., Perrotin, P., et al. (1998) Casein peptides release and passage to the blood in humans during digestion of milk and yogurt. Biochimie, 80, 155-165. doi:10.1016/S0300-9084(98)80022-9

[63] Matthews, D.M. (1991) Protein Absorption: Development and Present State of the Subject. Wiley-Liss, New York.

[64] Gardner, M.L.G. (1994) Absorption of intact proteins and peptides. In: Johnson, L.R., Ed. Physiology of the Gastrointestinal Tract, Raven Press, New York, 1795-1820.

[65] D’Eufemia, P., Celli, M., Finocchiaro, R. Pacifico, L., Viozzi, L., Zaccagnini, M., et al. (1996) Abnormal intestinal permeability in children with autism. Acta Paediatrica, 85, 1076-1079. doi:10.1111/j.1651-2227.1996.tb14220.x

[66] Lambert, M.T., Bjarnasson, I., Connelly, J., et al. (1989) Small intestine permeability in schizophrenia. The British Journal of Psychiatry, 155, 619-622.

[67] Wood, N.C., Hamilton, I., Axon, A.T.R., et al. (1987) Abnormal intestinal permeability. An aetiological factor in chronic psychiatric disorders? The British Journal of Psychiatry, 150, 853-856. doi:10.1192/bjp.150.6.853

[68] de Magistris, L., Familiari, V., Pascono, A., Sapone, A., Frolli, A., Iardino, P., et al. (2010) Alterations of the intestinal barrier in patients with autism spectrum disorders and in their first-degree relatives. Journal of Pediatric Gastroenterology and Nutrition, 51, 418-424.

[69] Jyonouchi, H., Sun, S. and Itokazu, N. (2002) Innate immunity associated with inflammatory responses and cytokine production against common dietary proteins in patients with autism spectrum disorder. Neuropsychobiology, 46, 76-84. doi:10.1159/000065416

[70] Bouras, M., Huneau, J.F. and Tome, D. (1996). The inhibition of intestinal dipeptidylaminopeptidase-IV promotes the absorption of enterostatin and des-arginineenterostatin across rat jejunum in vitro. Life Sciences, 59, 2147-2155. doi:10.1016/S0024-3205(96)00571-1

[71] Foltz, M., Meynen, E.E., Bianco, V., van Pålterink, C., Koning, T.M. and Kloek, J. (2007) Angiotensin converting enzyme inhibitory peptides from a lactotripeptide-enriched milk beverage are absorbed intact into the circulation. Journal of Nutrition, 137, 953-958.

[72] Husby, S., Jensenius, J.C. and Cant, A.J. (1984) Passage of undegraded dietary antigen into the blood of healthy adults. Scandinavian Journal of Immunology, 22, 83-92. doi:10.1111/j.1365-3083.1985.tb01862.x

[73] Kilshaw, P.J. and Cant, A.J. (1984) The passage of maternal dietary protein into human breast milk. International Archives of Allergy and Immunology, 75, 8-15. doi:10.1159/000233582

[74] Langer S.Z. (1997) 25 years since the discovery of presynaptic receptors: Present knowledge and future perspectives. Trends in Pharmacological Sciences, 18, 95-99. doi:10.1016/S0165-6147(96)01034-6
[75] Gardner, M.L.G. and Steffens, K.-J. (1995) Absorption of Orally Administered Enzymes. Springer Verlag, Berlin, Heidelberg, New York.

[76] Ermisch, A., Brust, P., Kretzchmar, R. and Buhle, H.-J. (1983) On the blood-brain barrier to peptides. (3H) betacasomorphin-5 uptake by eighteen brain regions in vivo. Journal of Neurochemistry, 41, 1229-1233. doi:10.1111/j.1471-4159.1983.tb00816.x

[77] Nyberg, F., Liberman, R., Lindstrøm, L.H., Lyrenäs, S., Koch, G. and Terenius, L. (1989) Immunoreactive betacasomorphin-8 in cerebrospinal fluid from pregnant and lactating women: Correlation with plasma level. The Journal of Clinical Endocrinology \& Metabolism, 68, 283289. doi:10.1210/jcem-68-2-283

[78] Bauer, K. and Kornhuber, J. (1987) Blood brain barrier in schizophrenic patients. European Archives of Psychiatry \& Neurological Sciences, 236, 257-259. doi:10.1007/BF00380949

[79] Kirch, D.G., Alexander, R.C., Suddath N.R.I., Papadopoulos, N.M., Kaufmann, C.A., Wyatt, D. and Wyatt, R.J. (1992) Blood-CSF barrier permeability and central nervous system immunoglobulin $\mathrm{G}$ in schizophrenia. Journal of Neural Transmission, 89, 219-232. doi:10.1007/BF01250674

[80] Paul, K.-D., Henker, J., Todt, A. and Eysold, R. (1985) EEG-Befunde zoeliakikranken kindern in abhängigkeit von der ernährung. Zeitschrift fur klinische Medizin, 40, 707-709.

[81] Uhlig, T., Merkenschlager, A., Brandmaier, R. and Egger J. (1997) Topographic mapping of brain electrical activity in children with food-induced attention deficit hyperactivity disorder. European Journal of Pediatrics, 156, 557-561. doi:10.1007/s004310050662

[82] Geissler, A., Andus, T., Roth, M., Kullman, F., Caesar, L., Held, P., et al. (1996) Focal white matter lesions in brain of patients with inflammatory bowel disease. Lancet, 345, 89-90.

[83] Hart, P.E., Gould, S.R., MacSweeney, J.E., Clifton, A. and Schon, F. (1998) Brain white matter lesions in inflammatory bowel disease. Lancet, 351, 1558. doi:10.1016/S0140-6736(05)61123-3

[84] Heyman, M. and Desjeux, J.F. (2000) Cytokine-induced alteration of epithelial barrier to food antigens in disease. Annals of the New York Academy of Sciences, 915, 304311. doi:10.1111/j.1749-6632.2000.tb05258.x

[85] Alander, T., Svärdsudd, K., Johansson, S.E. and Agreus, L. (2005) Psychological illness is commonly associated with functional gastrointestinal disorders and important to consider during patient consultation: A population-based study. BMC Medicine, 3, 8-20. doi:10.1186/1741-7015-3-8

[86] Haug, T.T., Mykletun, A. and Dahl, A.A. (2005) Are anxiety and depression related to gastrointestinal symptoms in the general population? Scandinavian Journal of Gastroenterology, 37, 294-298. doi:10.1080/003655202317284192

[87] Pynnönen, P.A., Isometsä, E.T., Verkesalo, M,A., Kähkönen, S.A., Sipilä, I., et al. (2005) Gluten-free diet may 
alleviate depressive and behavioural symptoms in adolescents with coeliac disease: A prospective follow-up case-series study. BMC Psychiatry, 8, 14-19.

[88] Reiter, P.J. (1926) Extrrapyramidal motor-disturbances in Dementia Praecox. Acta Psychiatrica et Neurologica Scan- dinavica, 1, 287-310. doi:10.1111/j.1600-0447.1926.tb11031.x

[89] Hemmings, G.P. (2004) Schizophrenia. Lancet, 364, 13121313. doi:10.1016/S0140-6736(04)17181-X 